Imran Qadir ${ }^{1}$, Amjad Ali ${ }^{2}$

1Department of Management Sciences, University of Haripur, Haripur, Pakistan

${ }^{2}$ COMSATS Institute of Information Technology, Abbottabad, Pakistan

\title{
Importance of Logistics Processes for Customer Service and Firm Performance: Evidence from Furniture Industry of Pakistan
}

DOI:10.7595/management.fon.2017.0026

\begin{abstract}
Research Question: This study examines the relationship between logistics processes, customer service and firm performance in the furniture industry of Pakistan. Motivation: Furniture industry in Pakistan comprises small and medium enterprises wherein production is mainly labor intensive. Therefore, the currentstudy also investigates the mediating role of manufacturing flexibility for the relationship of logistics processes and customer service. The paper applies the logistics models developed by Bowesox (1974), Green et al. (2008), and Tracey (1998) to furniture industry. Idea: The core idea of the paper is to measure the effects of logistics process on customer service and the performance of furniture manufacturing firms. The study takes the logistics process as an independent variable, the customer service as the first dependent variable and manufacturing performance as a moderating variable. Data: Primary data on logistics, customer service, manufacturing flexibility and firm performance were conveniently collected through a questionnaire from owners/managers of 61 furniture manufacturing firms. Tool: Descriptive statistics, correlation and regression analyses were run to draw the results. Findings: Logistics processes positively affect customer service and firm performance. Customer service also exerts a positive effect on firm performance while the moderating role of manufacturing flexibility was not supported for the relationship of logistics processes and customer service. Contribution: Through efficiency in logistics processes, furniture manufacturing firms can serve customers in a superior way to ultimately achieve improved firm performance. The framework being restricted to efficiency of logistics processes only constitutes an important limitation of the study.
\end{abstract}

Keywords: Logistics Processes, Customer Service, Firm Performance, Furniture Industry

JEL Classification: L25, L68, M11

\section{Introduction}

Logistics is the management of flows - products, finance, information - between business functions . Logistics forms the core part of the supply chain along with procurement, new product development, marketing, operations, finance and customer service. In the past, logistics was considered to perform a supportive role to these functional areas but now it has been given a far-reaching strategic role. The importance of logistics has increased immensely with advancements in communication and transportation technology . Logistics has a crucial role to play even in realizing the goal of regional economic integration and development (Tongzon, 2011). Logistics has a broader impact than just transaction cost and on-time delivery (Kumar, Andersson, \& Rehme, 2010). Hence, when process, market and information strategies are coordinated with overall logistics strategy with a clear focus on customer service, then logistics contributes to organizational competitive responsivenessas well . So, a well-coordinated logistics strategy improves customer service effectiveness as well (Kohn, McGinnis, \& Kara, 2011). Traditionally, companies tried to keep fully owned supply chains with the concepts of forward and backward vertical integration. Due to intense competition, businesses are now targeting specialized fields to build core competencies in specific areas and strive to gain competitive advantage by delivering better solutions to customers . 
Logistics management is vital for organizations that strive to achieve competitive advantage (, build core competencies, expand business through strategic alliances and accomplish customer value addition . It can be a unique resource for organizations that is difficult to be copied by competing firms (Leuschner, Charvet, \& Rogers, 2013). It helps to attain a desirable firm performance. The use of the latest logistics management practices results in the reduction of stocks, cost of production and lead time. Moreover, it increases the supply chain efficiency, ability to focus on core business, quality, expansion of production flexibility, and accelerated capital turnover. This results in lowered production costs and enhanced customer satisfaction through high quality delivery. To increase the efficiency of logistics processes, the role of different variables has been investigated, for instance, frequent delivery, smaller lot size, lower on-hand inventory, reduced production cycles and efficient inventory management .

To build responsive supply chains, firms must have to work on to get enhanced commitment from top management and trust based relationships with supply chain partners . In Pakistan, researchers have examined the relationships of uncertainties, human resource management practices, transportation outsourcing , supply chain management competence and supply chain strategy with the supply chain effectiveness or performance. Researchers have also investigated the supply chains of aviation, dairy, textile, and pharmaceutical industries from various aspects. Furthermore, concluded that customer satisfaction can be enhanced by improving the effectiveness of supply chain management in the airline industry of Pakistan. However, little is known about the furniture industry in Pakistan. This study aims to examine the relationship between logistics, customer service and firm performance in the furniture industry of Pakistan.

\section{Literature Review}

Best value supply chains practice strategic supply chain management to excel in terms of speed, quality, cost and flexibility . Logistics management positively affects the supply chain management because advanced logistics processes help companies to streamline desired operations and processes. This makes them more flexible and adaptive to the changing demands of customers (. But, use of advanced logistics practices requires proper planning as it does not always bear positive results. Entrepreneurial supply chain management (SCM) competence of manufacturing firms results in the development of better SCM strategies, which leads to improved performance. The efficiency of outbound flows depends upon inbound logistics of the same supply chain. Companies that consider logistics while outsourcing various projects improve their time efficiency. Productivity of manufacturing organizations increases by reducing through put time in logistics chains .

Nowadays, logistics is practiced as an integrated system/process developed through collaboration of different activities. Internal integration within organizations promotes external integration with customers and suppliers as well. Similarly, coordination between marketing and logistics functions is a prerequisite in making a supply chain a success .I ntegrated supply chain management allows organizations to deliver products to customers in a more timely and effective manner (Tan, 2001). Organizations need to keep their customers satisfied by approaching them before and after sales .

Proficiency in inbound logistics, outbound logistics, spanning processes and communication enhances the efficiency of overall logistical processes. All of these four variables are responsible for smooth working of inbound and outbound flows. Smooth logistics flow results in timely delivery, on-time order fulfillment and quicker fill rate. Different performance measures have been used to calculate the value created by logistics processes - customer satisfaction, customer value added, total cost analysis, profitability analysis and shareholder value. Customer satisfaction is the most commonly used measure to judge the innovation and performance of logistics (Lambert\& Burduroglu, 2000). Thus, the need for a high level of customer service motivates the management to develop a well thought-out and coordinated logistics strategy that optimizes efficiency, customer focus and information flow throughout the channel (Kohn et al., 2011). Improvement of delivery punctuality in logistics chains eventually leads to higher customer satisfaction. Manufacturing firms that aspire to become leaders in customer service must sustain certain types of capabilities regardless of the industry they compete in. And efficient logistics processes are critical in sustaining high levels of customer service. 
H1: There is a positive effect of logistics processes (H1), inbound logistics (H1a), outbound logistics (H1b), logistical spanning processes (H1c), and communication (H1d) on customer service.

Customer service has been critical in developing positive goodwill among customers and an important source of customer satisfaction . In the value chain concept, Porter (1991) shows the role of customer service along with other primary activities of supply chain to enhance firm performance. Various studies used different parameters to measure firm performance, for example,profitability, return on investment, productivity, sales per employee, capacity utilization and efficiency. Furthermore, specific parameters for logistics performance include logistics costs, delivery service, capital tied up in logistics, logistics cost per unit sold and cycle time. Customer service interventions exert a positive effect on customer satisfaction which in turn affects sales performance (Sulek, Lind, \& Marucheck, 1995). Additionally, customer service interventions such as order fulfillment exert a direct effect on sales performance as well . Improvement in customer service creates goodwill of the company among customers, which makes them more loyal. Enhanced customer service also keeps customers more satisfied. Consequently, they buy more of its products/services, which results in increased sales volume and profit. It increases the company's market share and improves its competitive position. The ability of firms to offer excellent customer service results in developing loyal customers, additional business through recommendations and improved financial performance.

\section{Hypothesis 2: There is a positive relationship between customer service and firm performance}

Betterment in customer service of a company results in the improvement of firm performance. The progress in customer service, however, is actually due to efficiency of logistical processes . Logistics activities influence firm performance mainly in terms of cost and inventory control (). Research also shows positive effect of supply chain fit and collaboration on financial performance of firms (Cao, \& Zhang, 2011; Wagner, GrosseRuyken, \& Erhun, 2012). Highly performing firms are superior in terms of delivery of service and product variety in comparison with low performing firms (Tracey \& Tan, 2001). This implies that the efficiency of logistical processes actually dictates firm performance. Research studies prove a significant impact of logistics service performance upon firm performance ). Internal collaboration affects logistics performance which further improves marketing performance (. Firms that have gained logistical competitive capability show higher financial performance (Ojha, Gianiodis, \& Manuj, 2013). The concept of value chain also highlights the role of inbound and outbound logistics to create value to achieve better firm performance (Porter, 2008).

H3: There is a positive relationship between (H3) logistics processes, (H3a) inbound logistics, (H3b) outbound logistics, $(\mathrm{H} 3 \mathrm{c})$ logistical spanning processes, $(\mathrm{H} 3 \mathrm{~d})$ communication and firm performance

The importance of manufacturing to organizational performance is of critical significance . Quesada-Pineda and Gazo (2007) report a positive relationship between best manufacturing practices and firm performance in furniture industry. For logistics firms, flexible capacity management has been suggested as a fundamental strategy (Delfmann, Albers, \& Gehring, 2002). So, manufacturing flexibility is crucial for customer service and consequently a competitive position of an organization. Flexibility was solely considered as an adaptive response to environmental uncertainty . But Gerwin (1993) suggests that manufacturing flexibility is not only an adaptive response but also a proactive function in creating uncertainties that competitors cannot deal with. One way of achieving flexibility is through advanced process technology. Earlier research on manufacturing flexibility concentrated only on production planning, scheduling, control and investment, especially for advanced process technology. However, Gerwin proposed a conceptual model which serves as a foundation to work on strategic aspects of flexibility. Manufacturing ability of a firm to produce a variety of quality goods in minimum time affects the capacity of logistics processes to enhance customer service. Firms with flexible manufacturing approach fulfill changing customer demands by producing a variety of products in lesser time. An advanced process technology makes flow of material and goods through input, transformation and output stages much more efficient. The efficiency of logistical processes is enhanced by manufacturing flexibility which in turn has a significant positive effecton customer service. However, benefits gained through advanced process technology can easily be neutralized if logistical processes are inefficient .

H4: Manufacturing flexibility moderates the relationship between logistics processes and customer service. 


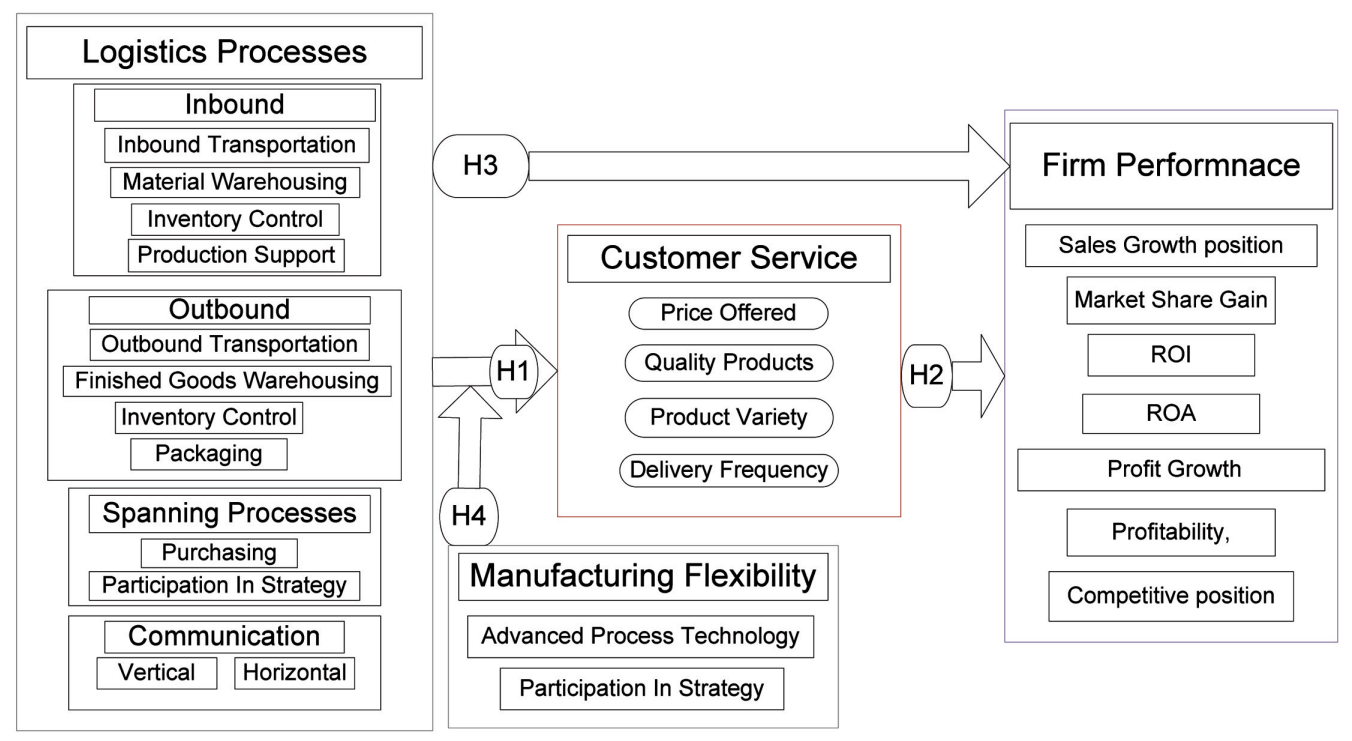

Figure 1: Theoretical Framework based on Bowersox (1974), Green et al. (2008) andTracey (1998)

\section{Research Methodology}

The population of the study comprises Furniture Manufacturing Firms in Pakistan. Primary data were collected from firms located in Gujrat, Chiniot, Islamabad and some other cities. The questionnaire was distributed to 100 conveniently selected companies, out of which only 61 companies provided useable data. Priority was given to get data from firm owners, otherwise senior managers were requested.

A total of 34 items were asked to measure logistics processes that comprise four sub variables - inbound logistics, outbound logistics, spanning processes and communication (Bowersox, 1974). Customer service was measured through15 questions. Firm performance was assessed through seven self-reported questions on profit growth, profitability, market share, sales volume growth, return on investments, return on assets and competitive position of the firm. Manufacturing flexibility was computed through six questions. Two different five-point Likert type scales ranging from 'Strongly Disagree' to 'Strongly Agree' and 'Never' to 'Always' were used to tap responses against logistics processes, customer service and manufacturing flexibility . An extra option of 'Not Applicable' against these questions was also provided to respondents in case a question was not relevant to their firm, market or industry. Another five-point Likert scale ranging from 'Well below industry average' to 'Well above industry average' was used to measure firm performance ).

\section{Results}

The age of the respondents varied from 20 years to 60 years, with a mean value of 37 years of age. Almost all of the respondents (60) were male. Nearly half of the respondents (49.2\%) had earned at least a bachelors degree while the rest of the respondents were 'intermediate, matriculation or below'. The average length of service in the current firm was 9 years while an average length of total experience was 16 years. A majority of the respondents (44.3\%) were owners, $24.6 \%$ were senior level managers, $18 \%$ middle level managers and $13.1 \%$ were operational level managers. Out of $61 \mathrm{firms}, 32.8 \%$ of were form Chiniot, $24.6 \%$ from Islamabad, $18 \%$ from Gujrat, $11.5 \%$ from Peshawar, and $13.1 \%$ were from other cities. The average number of employees in a given firm was 41 and the average age of firms was 18 years. Descriptive statistics and correlation among all the variables are shown in Table 1. The results show a moderate correlation of logistic processes with firm performance $\left(.498^{\star *}\right)$, customer service $\left(.556^{\star *}\right)$ and manufacturing flexibility $\left(.566^{* *}\right)$. There is a weak association $\left(.32^{*}\right)$ of customer service with firm performance. Manufacturing flexibility has a moderate association $\left(.542^{\star *}\right)$ with firm performance. 
Table 1:Descriptive statistics and correlations among variables

\begin{tabular}{lcccccc}
\hline & Mean & Std. Dev. & Log. Eff. & Firm Perf. & Cust. Serv. Manf. Flex. \\
\hline 1. Log. Eff. & 3.9 & .35 & 1 & & & \\
2. Firm Perf. & 3.5 & .99 & $.498^{* *}$ & 1 & & \\
3. Cust. Serv. & 4.12 & .32 & $.556^{* *}$ & $.320^{*}$ & 1 & \\
4. Manf. Flex. & 4.12 & .64 & $.566^{* *}$ & $.542^{* *}$ & .169 & 1 \\
\hline
\end{tabular}

**. Significant at .01 (2-tailed) *. Significant at .05 (2-tailed)

The first hypothesized relationship of logistic efficiency with customer service was found to be highly significant with the beta value of .556 and $R$ square value of .309 as shown in Table 2 . The beta value shows that a one unit change in logistics processes brings about .556 unit change in customer service. The $\mathrm{R}$ square value asserts that $30.9 \%$ of the variation in customer service can be explained by the corresponding changes in logistics processes. Among the sub indicators of logistics processes, inbound logistics has the highest Beta of .490 , followed by .439 of outbound logistics and .438 of communication with customer service. Spanning processes were not a predictor of customer service. This supports hypotheses $\mathrm{H} 1, \mathrm{H} 1 \mathrm{a}, \mathrm{H} 1 \mathrm{~b}$ and $\mathrm{H} 1 \mathrm{~d}$ while $\mathrm{H} 1 \mathrm{c}$ was not supported.

Table 2: Regression analyses

\begin{tabular}{cccccc}
\hline Hypothesis & IV & DV & Beta & Sig. & R Square \\
\hline $\mathrm{H} 1$ & LE & CS & .556 & .000 & .309 \\
$\mathrm{H} 1 \mathrm{a}$ & Inbound log. & $\mathrm{CS}$ & .490 & .000 & .240 \\
$\mathrm{H} 1 \mathrm{~b}$ & Outbound log. & $\mathrm{CS}$ & .439 & .000 & .193 \\
$\mathrm{H} 1 \mathrm{c}$ & Spanning Pro. & $\mathrm{CS}$ & .248 & .054 & .062 \\
$\mathrm{H} 1 \mathrm{~d}$ & Communication & $\mathrm{CS}$ & .438 & .000 & .192 \\
$\mathrm{H} 2$ & $\mathrm{CS}$ & $\mathrm{FP}$ & .320 & .012 & .102 \\
$\mathrm{H} 3$ & $\mathrm{LE}$ & $\mathrm{FP}$ & .498 & .000 & .248 \\
$\mathrm{H} 3 \mathrm{a}$ & Inbound log. & $\mathrm{FP}$ & .507 & .000 & .257 \\
$\mathrm{H} 3 \mathrm{~b}$ & Outbound log. & $\mathrm{FP}$ & .337 & .008 & .114 \\
$\mathrm{H} 3 \mathrm{c}$ & Spanning Pro. & $\mathrm{FP}$ & .393 & .002 & .155 \\
$\mathrm{H} 3 \mathrm{~d}$ & Communication & FP & .290 & .023 & .084 \\
\hline
\end{tabular}

The second hypothesized relationship of customer service with firm performance was found to be significant with a slope of .320 and $\mathrm{R}$ square value of .102 . It means that a one unit change in customer service brings about .32 unit change in firm performance and $10.2 \%$ of the variation in firm performance can be accounted for by the respective changes in customer service. So, $\mathrm{H} 2$ of the study was also supported. The third hypothesis of logistics processes with firm performance was also confirmed with a beta value of .498 and $R$ Square value of .248. This reveals that a one unit change in logistics processes brings about .498 unit change in firm performance and $24.8 \%$ of the variation in firm performance can be explained by the corresponding changes in logistics processes. All the sub hypotheses of $\mathrm{H} 3(\mathrm{H} 3 \mathrm{a}, \mathrm{H} 3 \mathrm{~b}, \mathrm{H} 3 \mathrm{c}$ and $\mathrm{H} 3 \mathrm{~d})$ were also confirmed.

For the fourth hypotheses, step-wise hierarchal regression analysis was performed to test a moderating role of manufacturing flexibility for the relationship of logistic processes and customer service. The beta value for interaction term (logistics processes $\mathrm{x}$ manufacturing flexibility) is not significant in Model 3 (see Table 3). So, the moderating role of manufacturing flexibility was not supported. Somehow, .043 change in $R$ square was found when interaction term was added in Model 3. 
Table 3:Regression analysis results showing moderating role of manufacturing flexibility

\begin{tabular}{lccc}
\hline & Model 1 & Model 2 & Model 3 \\
\hline Constant & $4.126^{\star}$ & $4.126^{\star}$ & $4.155^{\star}$ \\
Logistics processes & $.506^{\star}$ & $.616^{\star}$ & $.613^{\star}$ \\
Manf. Flex. & & -.106 & -.133 \\
Log. Eff. ${ }^{\star}$ Manf. Flex. & & & -.233 \\
R Square & .309 & .340 & .383 \\
Adj. R Square & .297 & .317 & .350 \\
R Square Change & .309 & .031 & .043 \\
Sig. F Change & .000 & .103 & .052 \\
\hline
\end{tabular}

Dependent Variable: Customer service * Sig at .05

\section{Discussion}

Based on findings of previous research, it was hypothesized that logistics efficiency exerts a positive effect on customer service. The results of the study prove that logistics efficiency positively affects the customer service of furniture manufacturing firms. The finding is consistent with earlier research. This shows that companies that are proficient in their logistics processes can deliver and maintain higher levels of customer service . Results also confirm that the indicators of logistics processes - inbound logistics, outbound logistics and communication - exert a significant effect on customer service. However, the study could not prove a significant effect of spanning process on customer service. Literature articulates that spanning processes are related to strategic management of firms and they have to do more with performance of firms as compared to its customer service .

Multiple studies establish that companies with superior customer service show excellent results in their financial and marketing performance. Viewing this, a significant relationship between customer service and firm performance was hypothesized. The results concluded that customer service exerts a positive influence on firm performance. Satisfied customers of a firm buy more of its products which leads to increased sales volume, profit and market share.

Researchers are of the opinion that logistics processes are highly important in achieving outstanding results in terms of firm performance. The current study confirms a positive effect of logistics processes on firm performance. Thus, firms which ensure higher efficiency in logistics processes tend to achieve higher firm performance.

It is advocated that manufacturing flexibility plays a moderating role in the relationship between logistics processes and customer service. However, the study could not prove a moderating role of manufacturing flexibility for the said relationship. A plausible reason is maybe that roles of advanced technologies and flexible processes are not crucial in the furniture industry of Pakistan because it is a labor-intensive industry and emphasis is given to handmade wooden furniture. Similarly, Cho et al. (2008) could not prove an interactive effect of logistic outsourcing for the relationship of logistics capability and firm performance.

\section{Conslusion}

The study concludes that furniture firms that have developed proficient logistical processes deliver a superior customer service.This helps them to retain existing customers and tempt more potential customers in comparison with their competitors. The study also proves positive effects of inbound logistics, outbound logistics and communication on firm performance. It is also proved that customer service positively impacts firm performance. Hence, companies having efficient logistics processes and quality customer service experience high returns in performance both financially and competitively. Similarly, argued that to achieve increased sales and larger market share, firms need to develop such logistics processes that are responsive to customers when taking orders, communicating with them and making timely deliveries. The study could not prove a relationship of spanning process with firm performance, either. The study also failed to establish a moderating role of manufacturing flexibility for the relationship of logistical processes and customer service. 
The research is based on primary data collected from owners or managers of furniture manufacturing firms located in three different cities. This research has practical implications for owners and managers of furniture firms in Pakistan. This endeavor provides foundations for evaluating the performance and customer service of firms with respect to their logistics processes. By achieving efficiency in logistics processes, companies can serve customers in a better way that ultimately improves financial performance. To some extent, furniture firms may enhance performance by directly improving the levels of customer service.

\section{Limitations and Directions for Further Research}

The first limitation of the study is its attempt to investigate into firm performance solely on the basis of logistics processes while logistics needs to be integrated with other functional areas - marketing, finance, HR, product development - to achieve improved firm performance (). The second limitation is self-reported data collected from a single source, that is, owner/manager of the firm. This may have produced biased results because of social desirability. The third limitation is the use of a convenient sampling technique and small sample size which restricts generalizability of results.

To achieve better results, future researchers may employ some qualitative research designs such as case study and interview method. Instead of self-reported data, future studies may use some objective measures, e.g., net-profit as a proxy of firm performance. Future research can be conducted by selecting larger sample sizes through more sophisticated probability sampling techniques such as simple random sampling.

\section{REFERENCES}

[1] Akbar, I., Muzaffar, M., \& Rehman, K. U. (2012). Entrepreneurial supply chain management competence: Performance of manufacturing small and medium enterprises. International Journal of Management \& Organizational Studies, 1(2), 39-46.

[2] Azevedo, S. G.,\& Ferreira, J. M. (2007). The linkage between logistics activities and firms' performance: An empirical study. Retrieved fromhttp://papers.ssrn.com/sol3/papers.cfm?abstract_id=1030287

[3] Bechtel, C., \& Jayaram, J. (1997). Supply chain management: a strategic perspective- The International Journal of Logistics Management, 8(1), 15-34.

[4] Bernon, M., \& Cullen, J. (2007). An integrated approach to managing reverse logistics. International Journal of Logistics: Research and Applications, 10(1), 41-56.

[5] Bhatnagar, R., \& Viswanathan, S. (2000). Re-engineering global supply chains: Alliances between manufacturing firms and global logistics services providers. International Journal of Physical Distribution \& Logistics Management, 30(1), 13-34.

[6] Bowersox, D. J. (1974). Logistical management: a systems integration of physical distribution management, material management, and logistical coordination: New York: Macmillan.

[7] Bowersox, D. J., Daugherty, P. J., Droge, C. L., Germain, R. N., \& Rogers, D. S. (1992). Logistics excellence: It's not just business as usual. Burlington, MA: Digital Press.

[8] Cao, M., \& Zhang, Q. (2011). Supply chain collaboration : Impact on collaborative advantage and firm performance. Journal of Operations Management, 29, 163-180. http://doi.org/10.1016/j.jom.2010.12.008

[9] Chen, H., Mattioda, D. D., \& Daugherty, P. J. (2007). Firm-wide integration and firm performance. The International Journal of Logistics Management, 18(1), 5-21.

[10] Cho, J. J.-K., Ozment, J., \& Sink, H. (2008). Logistics capability, logistics outsourcing and firm performance in an e-commerce market. International Journal of Physical Distribution \& Logistics Management, 38(5), 336-359. http://doi.org/10.1108/09600030810882825

[11] Chopra, S., \& Meindl, P. (2007). Supply chain management. Strategy, planning \& operation. New Jersey: Prentice Hall.

[12] Cooper, M. C., \& Ellram, L. M. (1993). Characteristics of supply chain management and the implications for purchasing and logistics strategy. The International Journal of Logistics Management, 4(2), 13-24.

[13] Crum, M., Poist, R., \& Daugherty, P. J. (2011). Review of logistics and supply chain relationship literature and suggested research agenda. International Journal of Physical Distribution \& Logistics Management, 41(1), 16-31.

[14] D'Souza, D. E. (2002). Toward an understanding of how organizations create manufacturing flexibility. Journal of Managerial Issues, 4(4), 470-485. 
[15] Das, A., \& Handfield, R. B. (1997). Just-in-time and logistics in global sourcing: an empirical study. International Journal of Physical Distribution \& Logistics Management, 27(3/4), 244-259.

[16] Day, G. S. (1994). The capabilities of market-driven organizations. Journal of Marketing, 58(4), 37-52.

[17] Delfmann, W., Albers, S., \& Gehring, M. (2002). The impact of electronic commerce on logistics service providers. International Journal of Physical Distribution \& Logistics Management, 32(3), 203-222. http://doi.org/10.1108/09600030210426539

[18] Dornier, P.-P., Ernst, R., Fender, M., \& Kouvelis, P. (2008). Global operations and logistics: Text and cases. New York: John Wiley \& Sons.

[19] Drucker, P. F. (1990). The emerging theory of manufacturing. Harvard Business Review, 68(3), 94-102.

[20] Faisal, M. (2015). Research analysis on barriers to green supply chain management in pharmaceutical industries. Review of Public Administration and Management, 3(1), 1-5. http://doi.org/10.4172/23157844.1000176

[21] Fredriksson, A., \& Johansson, E. (2009). Integrating logistics into the outsourcing process. International Journal of Logistics: Research and Applications, 12(4), 281-298.

[22] Gerwin, D. (1993). Manufacturing flexibility: a strategic perspective. Management Science, 39(4), 395410.

[23] Ghalayini, A. M., \& Noble, J. S. (1996). The changing basis of performance measurement. International Journal of Operations \& Production Management, 16(8), 63-80.

[24] Green, K. W., Whitten, D., \& Inman, R. A. (2008). The impact of logistics performance on organizational performance in a supply chain context. Supply Chain Management: An International Journal, 13(4), 317-327. http://doi.org/10.1108/13598540810882206

[25] Gupta, Y. P., \& Goyal, S. (1989). Flexibility of manufacturing systems: concepts and measurements. European Journal of Operational Research, 43(2), 119-135.

[26] Hall, R. (1992). The strategic analysis of intangible resources. Strategic Management Journal, 13(2), 135-144.

[27] Hayat, K., Abbas, A., Siddique, M., \& Cheema, K. U. R. (2012). A study of different factors that affecting the supply chain responsiveness. Academic Research International, 3(3), 345-356.

[28] Hayes, R. H., \& Pisano, G. P. (1994). Beyond world-class: The new manufacturing strategy. Harvard Business Review, 72(1), 77-84.

[29] Heskett, J. L., \& Schlesinger, L. (1994). Putting the service-profit chain to work. Harvard Business Review, 72(2), 164-174.

[30] Holcomb, M. C. (1994). Customer service measurement: a methodology for increasing customer value through utilization of the Taguchi strategy. Journal of Business Logistics, 15(1), 29-52.

[31] Houthoofd, N., Desmidt, S., \& Fidalgo, E. G. (2010). Analyzing firm performance heterogeneity: The relative effect of business domain. Management Decision, 48(6), 996-1009.

[32] Itami, H., \& Roehl, T. W. (1991). Mobilizing invisible assets. Boston: Harvard University Press.

[33] Jaafar, H., \& Rafiq, M. (2005). Logistics outsourcing practices in the UK: a survey. International Journal of Logistics: Research and Applications, 8(4), 299-312.

[34] Jahre, M., \& Fabbe-Costes, N. (2005). Adaptation and adaptability in logistics networks. International Journal of Logistics: Research and Applications, 8(2), 143-157.

[35] Kannan, V. R., \& Tan, K. C. (2005). Just in time, total quality management, and supply chain management: understanding their linkages and impact on business performance. Omega, 33(2), 153-162.

[36] Karimi, J., Somers, T. M., \& Gupta, Y. P. (2001). Impact of information technology management practices on customer service. Journal of Management Information Systems, 17(4), 125-158.

[37] Ketchen, D. J., \& Hult, G. T. M. (2007). Bridging organization theory and supply chain management : The case of best value supply chains. Journal of Operations Management, 25, 573-580. http://doi.org/10.1016/j.jom.2006.05.010

[38] Khan, N. R., Taha, S. M., Ghouri, A. M., Khan, M. R., \& Yong, C. K. (2013). The impact of HRM practices on supply chain management success in SME. Scientific Journal of Logistics, 9(3), 177-189.

[39] Kohn, J. W., McGinnis, M. A., \& Kara, A. (2011). A structural equation model assessment of logistics strategy. The International Journal of Logistics Management, 22(3), 284-305.

[40] Kumar, N., Andersson, D., \& Rehme, J. (2010). Logistics of low cost country sourcing. International Journal of Logistics: Research and Applications, 13(2), 143-160.

[41] Lado, A. A., Boyd, N. G., \& Wright, P. (1992). A competency-based model of sustainable competitive advantage: Toward a conceptual integration. Journal of Management, 18(1), 77-91.

[42] Lambert, D. M., \& Burduroglu, R. (2000). Measuring and selling the value of logistics. The International Journal of Logistics Management, 11(1), 1-17. http://doi.org/10.1108/09574090010806038 
[43] Leuschner, R., Charvet, F., \& Rogers, D. S. (2013). A meta-analysis of logistics customer service. Journal of Supply Chain Management, 49(1), 47-63.

[44] Lorentz, H., Töyli, J., Solakivi, T., \& Ojala, L. (2015). The effect of low-cost country sourcing on supply chain administration cost. International Journal of Logistics Research and Applications, 18(1), 1-15.

[45] Lynch, C. (2001). Developing a strategy for outsourcing. Logistics Management and Distribution, 40(6). T3-T7.

[46] Mubarik, S., Warsi, A. Z., Nayaz, M., \& Malik, T. (2012). Transportation outsourcing and supply chain performance: A study of Pakistan's pharmaceutical industry. South Asian Journal of Management Sciences, 6(2), 35-41.

[47] Muhammad, Z., Yi, F., Naz, A. S., \& Saleem, A. (2015). An investigation of justice in supply chain trust and relationship commitment - An empirical study of Pakistan. Journal of Competitiveness, 7(1), 71-87. http://doi.org/10.7441/joc.2015.01.05

[48] Murphy, P. R., \& Poist, R. F. (1996). Comparative views of logistics and marketing practitioners regarding interfunctional co-ordination. International Journal of Physical Distribution \& Logistics Management, 26(8), 15-28.

[49] Noor, N., Saeed, R., \& Lodhi, R. N. (2013). Factors affecting supply chain management effectiveness : A case of textile sector of Pakistan. Journal of Basic and Applied Scientific Research, 3(11), 56-63.

[50] Ojha, D., Gianiodis, P. T., \& Manuj, I. (2013). Impact of logistical business continuity planning on operational capabilities and financial performance. The International Journal of Logistics Management, 24(2), 180-209.

[51] Parashkevova, L. (2007). Logistics outsourcing-A means of assuring the competitive advantage for an organization. Vadyba/Management, 2(15), 29-38.

[52] Piriyakul, M., \& Kerdpitak, C. (2011). Mediation effects of logistics performance on collaboration and firm performance of palm oil companies: PLS path modeling. Journal of Management and Sustainability, $1(1), 90-98$.

[53] Porter, M. E. (1991). Capital disadvantage: America's failing capital investment system. Harvard Business Review, 70(5), 65-82.

[54] Porter, M. E. (2008). Competitive advantage: Creating and sustaining superior performance. Australia: Simon and Schuster.

[55] Quesada-Pineda, H., \& Gazo, R. (2007). Best manufacturing practices and their linkage to top-performing companies in the US furniture industry. Benchmarking: An International Journal, 14(2), 211-221.

[56] Rabinovich, E., Windle, R., Dresner, M., \& Corsi, T. (1999). Outsourcing of integrated logistics functions: an examination of industry practices. International Journal of Physical Distribution \& Logistics Management, 29(6), 353-373.

[57] Rafique, B. (2015). Impact of uncertainties on supply chain operations in Pakistan. South Asian Journal of Management Sciences, 9(1), 15-22.

[58] Rajahonka, M. (2013). Views of logistics service providers on modularity in logistics services. International Journal of Logistics Research and Applications, 16(1), 34-50.

[59] Rehman, Z.-U., Shakeel, M. H., \& Faraz, M. R. (2013). Impact of e procurement and logistics on effectivenss of supply chain management: A study of aviation industry in Pakistan. Jinnah Business Review, $1(2), 11-16$.

[60] Sahay, B. S., \& Mohan, R. (2006). 3PL practices: an Indian perspective. International Journal of Physical Distribution \& Logistics Management, 36(9), 666-689.

[61] Shamsi, M. I., \& Syed, S. A. (2015). A study of the logistics capability factors for an e-commerce market. FAST-NU Research Journal, 1(2), 143-149.

[62] Skinner, W. (1969). Manufacturing-The missing link in corporate strategy. Harvard Business Review, 47(3), 136-145.

[63] Stank, T. P., Daugherty, P. J., \& Ellinger, A. E. (1999). Marketing/logistics integration and firm performance. The International Journal of Logistics Management, 10(1), 11-24.

[64] Stock, J. R., \& Lambert, D. M. (2001). Strategic logistics management. Irwin Boston, MA: McGraw-Hill.

[65] Sulek, J. M., Lind, M. R., \& Marucheck, A. S. (1995). The impact of a customer service intervention and facility design on firm performance. Management Science, 41(11), 1763-1773.

[66] Svensson, G. (2001). The impact of outsourcing on inbound logistics flows. The International Journal of Logistics Management, 12(1), 21-35.

[67] Talib, N., \& Alam, M. A. (2016). The moderating role of organization culture in promoting external integration. NUML International Journal of Business \& Management, 11(2), 101-119. 
[68] Tan, K. C. (2001). A framwork of supply chain management literature. European Journal of Purchasing \& Supply Management, 7, 39-48.

[69] Tanskanen, K., \& Hameri, A.-P. (1999). Improving efficiency and productivity in logistics: A case study. International Journal of Logistics: Research and Applications, 2(2), 197-211.

[70] Tipu, S. A. A., \& Fantazy, K. A. (2014). Supply chain strategy, flexibility, and performance: A comparative study of SMEs in Pakistan and Canada. The International Journal of Logistics Management, 25(2), 399-416. http://doi.org/10.1108/IJLM-01-2013-0001

[71] Tongzon, J. (2011). Liberalisation of logistics services: the case of ASEAN. International Journal of Logistics: Research and Applications, 14(1), 11-34.

[72] Tracey, M. (1998). The importance of logistics efficiency to customer service and firm performance. The International Journal of Logistics Management, 9(2), 65-81.

[73] Tracey, M., \& Tan, C. L. (2001). Empirical analysis of supplier selection and involvement, customer satisfaction, and firm performance. Supply Chain Management: An International Journal, 6(4), 174-188.

[74] Wagner, S. M., Grosse-Ruyken, P. T., \& Erhun, F. (2012). The link between supply chain fit and financial performance of the firm. Journal of Operations Management, 30, 340-353. http://doi.org/10.1016/j.jom.2012.01.001

[75] Wheelwright, S. C., \& Kimberly, B. C. (1992). Revolutionary product development. New York: The Free Press.

[76] Wong, Y. Y., Maher, T. E., Nicholson, J. D., \& Gurney, N. P. (2000). Strategic alliances in logistics outsourcing.Asia Pacific Journal of Marketing and Logistics, $12(4)$ ), 3-21.

[77] Zakir, F., \& Rehman, A. (2015). Effect of poor supply chain on the customer satisfaction: Survey of flight delyas in Pakistan. International Journal of Management Sciences and Business Research, 4(12), 105111.

[78] Zubair, M., \& Mufti, N. A. (2015). Identification and assessment of supply chain risks associated with dairy products sector. Journal of Basic and Applied Sciences, 11, 167-175.

Received: 2017-06-24

Accepted: 2017-11-21
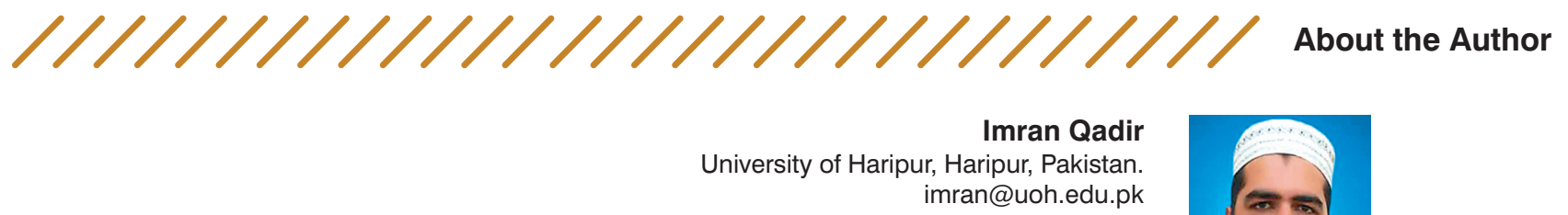

Imran Qadir is a lecturer of Marketing and Entrepreneurship at the Department of Management Sciences, University of Haripur, Pakistan. He is also the departmental focal person for Entrepreneurship and Business Incubation. He did his MS in Management Sciences from COMSATS Institute of Information Technology, Pakistan. His research interests include entrepreneurship, effectuation, marketing, supply chain, business models and business startups.

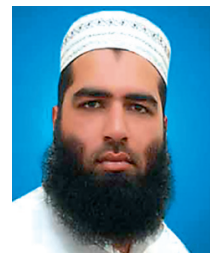

\section{Amjad Ali}

COMSATS Institute of Information Technology, Abbottabad, Pakistan amjad@ciit.net.pk

Amjad Ali is assistant professor at the Department of Management Sciences, COMSATS Institute of Information Technology, Abbottabad Campus, Pakistan. He holds a PhD in Management Sciences from Foundation University, Islamabad, Pakistan. He has ample experience in teaching and managing academic and marketing research. His research areas include supply chain management, organizational behaviour, knowledge sharing, emotional intelligence, and employee performance.

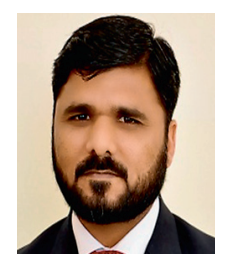

